\title{
Partie polityczne i ich elektoraty. Od sympatii do antagonizmu. Na przykładzie Platformy Obywatelskiej i Prawa i Sprawiedliwości
}

\begin{abstract}
Streszczenie: Od 2005 roku życie polityczne w Polsce w znaczącym stopniu zdominowane jest przez spór dwóch partii: Platformy Obywatelskiej (PO) oraz Prawa i Sprawiedliwości (PiS). Spór ten nie jest tylko rywalizacją liderów i członków partii na programy polityczne. To konfrontacja antagonistycznych światopoglądów wyborców oraz sympatyków obu partii. Jej symbolicznym początkiem są nieudane rozmowy między gremiami przywódczymi obu partii, które nie doprowadziły do powstania koalicyjnego rządu w 2005 roku. Intensywność sporu, toczonego w wielu środowiskach, skłania obserwatorów życia publicznego do formułowania tezy o dwóch metaforycznych Polskach, o dwóch obcych sobie plemionach. Autorzy naukowych i publicystycznych analiz tego fenomenu często wskazują na różnice w zakresie cech demograficznych i społecznych, jakimi charakteryzują się elektoraty obu partii. Odmienności te mają jednak drugorzędne znaczenie w stosunku do różnic w poglądach zwolenników PO i PiS na temat wydarzeń, problemów, zjawisk i osób istotnych dla partyjnych tożsamości. Istotną rolę w podtrzymywaniu i reprodukcji odmiennych światopoglądów sympatyków obu partii odgrywają media. Celem tekstu jest dokonanie charakterystyki cech oraz podzielanych poglądów sympatyków obu partii oraz analiza ewolucji ich sympatii i antypatii politycznych w ostatnich kilkunastu latach. Wnioski formułowane są na podstawie wtórnej analizy danych zebranych w latach 2001-2019 przez Centrum Badania Opinii Społecznej oraz przez innych badaczy.
\end{abstract}

Słowa kluczowe: Platforma Obywatelska, Prawo i Sprawiedliwość, sympatie i antypatie partyjne, elektorat, narracja, konflikt antagonistyczny

$\mathbf{Z}$ apewne wielu współczesnym młodym obserwatorom życia politycznego w Polsce w 2019 roku nie jest łatwo wyobrazić sobie, że liderzy dwóch głównych, opozycyjnych względem siebie ugrupowań politycznych - PO i PiS, kilkanaście lat wcześniej, w trakcie kampanii poprzedzającej wybory parlamentarne w 2005 roku, zapowiadali utworzenie wspólnego koalicyjnego rządu. I chociaż w wyborach tych obie partie uzyskały łącznie poparcie ponad 51,0\% wyborców, co znalazło odzwierciedlenie w 288 mandatach poselskich, to do powstania koalicyjnego rządu, już w kampanii wyborczej nazywanego rządem POPiS, nie doszło. Rozmowy potencjalnych koalicjantów zakończyły się niepowodzeniem, w efekcie czego PiS utworzył koalicję rządową z partiami: Samoobrona i Liga Polskich Rodzin (LPR), a PO stała się w parlamencie największą partią opozycyjną. Moment ten można uznać za symboliczny początek fundamentalnego sporu między PO a PiS, a opisujące go kategorie pojęciowe (w tym m.in. spór „III RP” z „IV RP”, spór „Polski liberalnej” z „Polską solidarną”) wkrótce stały się jednymi z kluczowych w opisach życia politycznego w Polsce po 2005 roku.

Konflikt między PO i PiS był tym bardziej zaskakujący, że obydwie partie, pomimo pewnych różnic programowych, wiele łączyło. Obie powstały w 2001 roku (PO w styczniu, a PiS w maju), obydwie były partiami postsolidarnościowymi, an- 
tykomunistycznymi, akcentującymi w swych programach potrzebę przeprowadzenia zmian w kraju. W jednych z pierwszych badań socjologicznych, w których sympatycy nowo utworzonych ugrupowań politycznych mieli możliwość uzasadnienia swych zamiarów oddania na nie głosu w wyborach parlamentarnych w 2001 roku, w obydwu potencjalnych elektoratach dominowały motywy związane z postulowanymi zmianami w kraju. Zwolennicy PO eksponowali w swych wypowiedziach przede wszystkim argumenty, że popierana przez nich partia stwarza szansę na pozytywne zmiany $(50,0 \%)$, ma dobry program gospodarczy $(44,0 \%)$ oraz fachowych polityków, którzy będą umieli pokierować krajem $(34,0 \%)$. Z kolei, potencjalni wyborcy PiS w sposób szczególny podkreślali, że politycy, na których chcą głosować są niezależni i nieuwikłani w układy z innymi partiami $(44,0 \%)$, stwarzają szansę na zmniejszenie przestępczości i poprawę bezpieczeństwa $(43,0 \%)$ oraz są uczciwi, wiarygodni, nieskorumpowani (34,0\%) (Pankowski, 2001a). Zwolennicy obydwu partii najczęściej spośród wszystkich badanych potencjalnych elektoratów partyjnych twierdzili, że wybór nowych ugrupowań wynika z tego, iż zawiedli się na tych partiach, na które głosowali w poprzednich wyborach.

\section{Wyborcy PO i PiS. Od sympatii do antypatii}

Niechęć do wcześniej popieranych partii, połączona z pragnieniem zmian, była istotnym czynnikiem łączącym elektoraty PO i PiS. Wymownym wskaźnikiem postrzeganej przez potencjalnych wyborców obu partii ich zbieżności programowej jest odsetek osób deklarujących chęć głosowania na jeszcze jedną partię oprócz tej, która jest przedmiotem pierwszego wyboru. W badaniach zrealizowanych w czerwcu 2001 roku, w których respondenci pytani o preferencje wyborcze, po raz pierwszy mogli w swych odpowiedziach uwzględnić PiS, sympatycy tej partii odpowiadając na pytanie: Gdyby mógł (mogła) Pan(i) głosować na kandydatów jeszcze jednej partii, to którą partię wybrał(a)by Pan(i) jako drugą?, najczęściej wskazywali na PO (26,0\%) (Pankowski, 2001). Z kolei, zwolennicy PO w odpowiedzi na to pytanie najczęściej wymieniali PiS $(19,0 \%)$. Dodatkowo, obie partie zajmowały odległe miejsca w rankingach ugrupowań, na które ich sympatycy na pewno by nie zagłosowali.

Ewolucję sympatii i antypatii zwolenników PO do PiS oraz zwolenników PiS do PO w wymowny sposób ilustrują dane zamieszczone w tabelach 1 i 2 . Pierwsza z nich zawiera odsetki sympatyków obu partii, których ankieterzy CBOS, w trakcie badań realizowanych w okresie 2001-2019, prosili o wskazanie partii, na które skłonni byliby głosować, mając możliwość oddania głosu nie na jedną, ale na dwie partie. $Z$ kolei, w tabeli 2 przedstawione zostały odsetki zwolenników obu partii, którzy w tym samym okresie, i w tych samych badaniach udzielali odpowiedzi na pytanie: Na które partie na pewno nie głosował(a)by Pan(i)? W przypadku wszystkich cytowanych badań w tabelach zaprezentowane zostały dwa ugrupowania najczęściej wymieniane przez obie kategorie badanych. W tabeli 1 były to partie cieszące się największą sympatią zwolenników PO i PiS, a w tabeli 2, takie, które były przez nich najczęściej odrzucane. $Z$ danych wynika, że w latach 2001-2005, w opiniach swoich sympatyków PO i PiS były ugrupowaniami o na tyle mało odmiennych programach, że w obu potencjalnych elektoratach stanowiły 
partie drugiego wyboru, czyli takie, na które oddano by głosy, gdyby można było głosować na kandydatów nie jednej, ale dwóch partii. Wzajemna sympatia obu elektoratów stale rosła, osiągając swój maksymalny poziom przed wyborami parlamentarnymi w 2005 roku. W podsumowaniu badań zrealizowanych w czerwcu 2005 roku, a więc na cztery miesiące przed wyborami parlamentarnymi, Agnieszka Cybulska, komentując fakt, iż prawie połowa (48,0\%) sympatyków PO jest skłonna poprzeć także PiS, a 44,0\% wyborców PiS, mając możliwość głosowania na jeszcze jedną partię, poparłaby PO, napisała: „Elektoraty obu tych ugrupowań są do siebie najbardziej zbliżone - ich zwolennicy uznają się wzajemnie za najbardziej atrakcyjną alternatywę wyborczą" (Cybulska, 2005a, s. 12).

Zwolennicy obu ugrupowań byli również dość zgodni w swych decyzjach dotyczących partii, na które nie oddaliby swego głosu (Tabela 2). Wprawdzie potencjalny elektorat PO liczniej wskazywał na Samoobronę, a nieco rzadziej na SLD, podczas gdy wśród sympatyków PiS częstotliwość wskazań na obie partie była odwrotna, ale żadne inne podmioty polityczne nie budziły tak dużej antypatii, jak dwie wymienione. W okresie największego nasilenia niechęci do tych ugrupowań, czyli przed wyborami parlamentarnymi w 2005 roku, w potencjalnym elektoracie PO Samoobronę, odrzucało 73,0\% osób, a SLD $63,0 \%$, a w potencjalnym elektoracie PiS - pierwszą z tych partii $47,0 \%$, a drugą $79,0 \%$ (Cybulska, 2005a, s. 10). Warto dodać, że zwolennicy PO i PiS byli zgodni także w tym, że taki sam, stosunkowo niewielki, bo liczący 3,0\%, odsetek wyborców każdej z partii nie oddałby głosu na drugą z partii.

Tabela 1

Alternatywne sympatie polityczne potencjalnych elektoratów PO i PiS w latach 2001-2019 (dane w \%)

\begin{tabular}{|c|c|c|c|}
\hline \multirow{2}{*}{$\begin{array}{l}\text { Badania } \\
\text { i data ich } \\
\text { realizacji }\end{array}$} & \multirow{2}{*}{$\begin{array}{l}\text { Gdyby mógt (mogla) Pan(i) glosować na kandydatów } \\
\text { jeszcze jednej partii, to która partię wybrat(a)by Pan(i) } \\
\text { jako druga? }\end{array}$} & \multicolumn{2}{|c|}{$\begin{array}{c}\text { Potencjalne elektoraty } \\
\text { (partie pierwszego wyboru) }\end{array}$} \\
\hline & & PO & PiS \\
\hline 1 & 2 & 3 & 4 \\
\hline $\begin{array}{l}\text { Czerwiec } 2001 \\
\text { CBOS, } \\
\text { BS/85/2001 }\end{array}$ & $\begin{array}{l}\text { PO } \\
\text { PiS } \\
\text { UW (Unia Wolności) } \\
\text { AWSP (Akcja Wyborcza Solidarność Prawicy) }\end{array}$ & $\begin{array}{c}- \\
19,0 \\
18,0 \\
17,0\end{array}$ & $\begin{array}{c}26,0 \\
- \\
2,0 \\
11,0\end{array}$ \\
\hline $\begin{array}{l}\text { Czerwiec } 2005 \\
\text { CBOS, } \\
\text { BS/100/2005 }\end{array}$ & $\begin{array}{l}\text { PO } \\
\text { PiS } \\
\text { PD-demokraci.pl } \\
\text { Samoobrona }\end{array}$ & $\begin{array}{r}- \\
48,0 \\
8,0 \\
6,0\end{array}$ & $\begin{array}{c}4,0 \\
- \\
0,0 \\
12,0\end{array}$ \\
\hline $\begin{array}{l}\text { Wrzesień } 2007 \\
\text { CBOS, } \\
\text { BS/149/2007 }\end{array}$ & $\begin{array}{l}\text { PO } \\
\text { PiS } \\
\text { LiD (koalicja SLD+SdP1+PD +UP) } \\
\text { PSL (Polskie Stronnictwo Ludowe) }\end{array}$ & $\begin{array}{r}- \\
8,0 \\
26,0 \\
9,0\end{array}$ & $\begin{array}{c}22,0 \\
- \\
3,0 \\
10,0\end{array}$ \\
\hline $\begin{array}{l}\text { Listopad } 2010 \\
\text { CBOS, } \\
\text { BS/151/2010 }\end{array}$ & $\begin{array}{l}\text { PO } \\
\text { PiS } \\
\text { SLD } \\
\text { PSL }\end{array}$ & $\begin{array}{r}- \\
5,0 \\
32,0 \\
13,0\end{array}$ & $\begin{array}{c}7,0 \\
- \\
14,0 \\
14,0\end{array}$ \\
\hline $\begin{array}{l}\text { Sierpień } 2015 \\
\text { CBOS, } \\
111 / 2015\end{array}$ & $\begin{array}{l}\text { PO } \\
\text { PiS (wraz z partiami koalicyjnymi) } \\
\text { SLD } \\
\text { Komitet wyborczy Pawła Kukiza (Ruch JOW) }\end{array}$ & $\begin{array}{r}- \\
8,0 \\
15,0 \\
8,0\end{array}$ & $\begin{array}{c}6,0 \\
- \\
5,0 \\
26,0\end{array}$ \\
\hline
\end{tabular}




\begin{tabular}{|l|l|c|c||}
\hline \multicolumn{1}{|c|}{ 2 } & \multicolumn{1}{c|}{$\begin{array}{c}\text { 2 } \\
\text { Październik }\end{array}$ PO } & - & 4 \\
2017 CBOS, & PiS (wraz z partiami koalicyjnymi) & 3,0 & 3,0 \\
$135 / 2017$ & Nowoczesna & 44,0 & 1,0 \\
& Komitet wyborczy Pawła Kukiza (Ruch JOW) & 8,0 & 42,0 \\
\hline Marzec & PO & - & 3,0 \\
2019 CBOS, & PiS (wraz z partiami koalicyjnymi) & 2,0 & - \\
$39 / 2019$ & Nowoczesna & 19,0 & 1,0 \\
& Komitet wyborczy Pawła Kukiza (Ruch JOW) & 3,0 & 30,0 \\
\hline
\end{tabular}

Źródło: Opracowanie własne na podstawie wybranych badań CBOS wymienionych w bibliografii.

Po zakończonych fiaskiem rozmowach koalicyjnych prowadzonych przez przedstawicieli PO i PiS jesienią 2005 roku, spór między partiami zaczął się nasilać i wkraczać w kolejne obszary życia publicznego. Eskalacji konfliktu oraz polaryzacji rozkładu poparcia i sympatii politycznych wyraźnie sprzyjał fakt, iż PO i PiS były partiami cieszącymi się zdecydowanie wyższym poparciem wyborców, niż inne ugrupowania. W przyspieszonych wyborach parlamentarnych przeprowadzonych w 2007 roku na PO i PiS oddano łącznie ponad 73,0\% głosów, w 2011 roku ponad 69,0\%, a w 2015 - ponad 61,0\%.

Tabela 2

Antypatie polityczne potencjalnych elektoratów PO i PiS w latach 2001-2019 (dane w \%)

\begin{tabular}{|c|c|c|c|}
\hline \multirow{2}{*}{$\begin{array}{l}\text { Badania i data ich } \\
\text { realizacji }\end{array}$} & \multirow{2}{*}{$\begin{array}{l}\text { Na które partie na pewno nie glosowal(a)by Pa- } \\
n(i) ?\end{array}$} & \multicolumn{2}{|c|}{$\begin{array}{c}\text { Potencjalne elektoraty } \\
\text { (partie pierwszego wyboru) }\end{array}$} \\
\hline & & PO & PiS \\
\hline 1 & 2 & 3 & 4 \\
\hline \multirow{4}{*}{$\begin{array}{l}\text { Czerwiec } 2001 \\
\text { CBOS, BS/85/2001 }\end{array}$} & $\mathrm{PO}$ & - & 15,0 \\
\hline & PiS & 2,0 & - \\
\hline & „Samoobrona” & 46,0 & 37,0 \\
\hline & SLD+UP+KPEiR & 54,0 & 59,0 \\
\hline \multirow{4}{*}{$\begin{array}{l}\text { Czerwiec 2005 } \\
\text { CBOS, BS/100/2005 }\end{array}$} & $\mathrm{PO}$ & - & 3,0 \\
\hline & PiS & 3,0 & - \\
\hline & „Samoobrona” & 73,0 & 47,0 \\
\hline & SLD+UP+KPEiR & 63,0 & 79,0 \\
\hline \multirow{5}{*}{$\begin{array}{l}\text { Wrzesień } 2007 \\
\text { CBOS, BS/149/2007 }\end{array}$} & PO & - & 35,0 \\
\hline & PiS & 59,0 & - \\
\hline & „Samoobrona” & 72,0 & 50,0 \\
\hline & LPR & 62,0 & 36,0 \\
\hline & LiD & 19,0 & 58,0 \\
\hline \multirow{4}{*}{$\begin{array}{l}\text { Listopad 2010 } \\
\text { CBOS, BS/151/2010 }\end{array}$} & $\mathrm{PO}$ & - & 50,0 \\
\hline & PiS & 70,0 & - \\
\hline & „Samoobrona” & 43,0 & 29,0 \\
\hline & SLD & 10,0 & 38,0 \\
\hline \multirow{4}{*}{$\begin{array}{l}\text { Sierpień } 2015 \\
\text { CBOS, } 111 / 2015\end{array}$} & PO & - & 63,0 \\
\hline & PiS & 68,0 & - \\
\hline & KORWiN & 43,0 & 25,0 \\
\hline & Twój Ruch & 13,0 & 28,0 \\
\hline \multirow{4}{*}{$\begin{array}{l}\text { Październik } 2017 \\
\text { CBOS, } 135 / 2017\end{array}$} & PO & - & 73,0 \\
\hline & PiS (wraz z partiami koalicyjnymi) & 82,0 & - \\
\hline & Wolność & 36,0 & 9,0 \\
\hline & Nowoczesna & 7,0 & 46,0 \\
\hline
\end{tabular}




\begin{tabular}{|l|l|r|c||}
\hline \multicolumn{1}{|c|}{ 2 } & \multicolumn{1}{|c||}{3} & 4 \\
\hline Marzec 2019 & PO & - & 68,0 \\
CBOS, 39/2019 & PiS (wraz z partiami koalicyjnymi) & 85,0 & - \\
& KORWIN & 29,0 & 10,0 \\
& Nowoczesna & 1,0 & 23,0 \\
\hline
\end{tabular}

Źródło: Opracowanie własne na podstawie wybranych badań CBOS wymienionych w bibliografii.

Malejącą po 2005 roku sympatię między elektoratami PO i PiS dobrze ilustrują dane zawarte w tabeli 1. Wyniki badań zrealizowanych we wrześniu 2007 roku ujawniły, że w porównaniu z tymi, które przeprowadzone były 2 lata wcześniej, skłonność sympatyków PiS do głosowania na PO zmniejszyła się o połowę (do 22,0\%), a zwolenników PO do oddania głosu na PiS, zmniejszyła się aż 6-krotnie (do 8,0\%) (Cybulska, 2007a, s. 6). Cytowane badania ujawniły również, że po raz pierwszy partią drugiego wyboru dla sympatyków PO stał się LiD (Lewica i Demokraci), czyli koalicja partii lewicowych, w której najbardziej wyrazistym uczestnikiem był SLD, czyli partia należąca do tych, które do roku 2005 były najczęściej przez zwolenników PO odrzucane. Od 2017 roku, pytani o partię drugiego wyboru, zwolennicy PO najczęściej wskazywali na Nowoczesną.

W potencjalnym elektoracie PiS, po 2005 roku, przez kilka kolejnych lat partią drugiego wyboru, chociaż wymienianą zdecydowanie rzadziej niż dawniej (ok. 20,0\% osób), wciąż była PO. W 2013 roku, zwolennicy PiS wskazywali najczęściej na Solidarną Polskę Zbigniewa Ziobry, a od 2015 roku ugrupowaniem drugiego wyboru dla sympatyków PiS stał się Komitet wyborczy Pawła Kukiza (Ruch JOW).

Jeszcze wyraźniej narastanie wzajemnej niechęci między PO a PiS widoczne jest w zestawieniu danych ilustrujących ewolucję antypatii partyjnych potencjalnych elektoratów obu ugrupowań (Tabela 2). W okresie obejmującym lata 2005-2007 antypatia wyborców PiS do PO wzrosła prawie 12-krotnie, gdyż z 3,0\% do 35,0\%, a wyborców PO do PiS prawie 20-krotnie, gdyż z 3,0\% do 59,0\% (Cybulska, 2007a, s.11). Dane te pozwalają także dostrzec rolę, jaką w eskalacji konfliktowych relacji między partiami odegrała katastrofa smoleńska w 2010 roku i jej następstwa. Jesienią 2010 roku zwolennicy PO, wśród partii, na które nie zagłosowaliby, zdecydowanie najczęściej wskazywali na PiS (70,0\%), a sympatycy PiS, zdecydowanie częściej od SLD (38,0\%), wymieniali PO (50,0\%) (Cybulska, 2010, s. 12). W kolejnych latach poziomy wzajemnej niechęci elektoratów PO i PiS osiągnęły jeszcze wyższe poziomy. Trafnym, wciąż zachowującym aktualność, komentarzem sytuacji politycznej w Polsce, są słowa Agnieszki Cybulskiej, która w omówieniu wyników badań przeprowadzonych w 2015 roku stwierdziła: „Chociaż pojawienie się nowych inicjatyw politycznych nieco odświeżyło tradycyjny, utrzymujący się od lat układ sympatii i antypatii partyjnych, zasadnicza linia dwubiegunowego podziału w dalszym ciągu się utrzymuje. Scenę polityczną nadal najsilniej różnicuje podział na linii PO-PiS. Elektoraty tych ugrupowań można określić jako najbardziej rozłączne" (Cybulska, 2015, s. 11). Potwierdzenie tych słów znaleźć m.in. można w rezultatach badań zrealizowanych w marcu 2019 roku, z których wynika, że 85,0\% zwolenników PO i 68,0\% sympatyków PiS na pewno nie oddałoby swego głosu na główną konkurencyjną partię (Cybulska, 2019, s. 8).

Czy owa „rozłączność” manifestująca się w deklarowanej wzajemnej niechęci wyborców PO do PiS oraz zwolenników PiS do PO znajduje odzwierciedlenie w obiektywnych różnicach w zakresie składów społecznych obu elektoratów? 


\section{Podobieństwa i różnice elektoratów partyjnych PO i PiS}

Poszukiwanie uwarunkowań zróżnicowania postaw politycznych w cechach usytuowania jednostek w strukturze społecznej ma w nauce kilkudziesięcioletnią tradycję (Berelson, Lazarsfeld, McPhee, 1954). Mniej lub bardziej rozbudowane zestawy takich cech pełnią w analizach funkcje zmiennych niezależnych, wyjaśniających absencję wyborczą, udział w głosowaniach, czy rozkład sympatii i antypatii partyjnych. Ten sposób opisu zachowań wyborczych ma ugruntowaną pozycję także w Polsce (Jasiewicz, 2002; Raciborski, 2003; Cześnik, 2007). Jest on również wykorzystywany w analizach rozkładu poparcia dla PO i PiS. Wynika z nich, że bardziej znaczące różnice między omawianymi elektoratami występują w przypadku takich cech jak: miejsce zamieszkania (niemal połowa, gdyż 47,0\% potencjalnego elektoratu PiS mieszka na wsi, a w elektoracie PO takich osób jest 23,0\%), wykształcenie (stosunkowo najliczniejszy odsetek wyborców PiS legitymuje się wykształceniem średnim, a wyborców PO - wyższym), struktura społeczno-zawodowa (o ile kadra kierownicza i specjaliści z wyższym wykształceniem stanowią 18,0\% elektoratu PO, to w elektoracie PiS tylko $7,0 \%)$, udział w praktykach religijnych (2/3 wyborców PiS uczestniczy w praktykach religijnych co najmniej raz w tygodniu, a wśród wyborców PO takich osób jest 39,0\%) oraz deklarowane poglądy polityczne $(68,0 \%$ wyborców PiS deklaruje poglądy prawicowe, a w elektoracie PO liczniejsze są osoby o poglądach centrowych i lewicowych - 63,0\%) (Pankowski, 2017).

Porównanie cech potencjalnych elektoratów obu partii z tymi, które odnotowano w pierwszych latach ich działalności, pozwala na konstatację, że zaobserwowane wówczas charakterystyczne różnice między ich składami społeczno-demograficznymi, w okresie ostatnich kilkunastu lat, stały się bardziej wyraźne. W porównaniu z elektoratem PiS, w elektoracie PO liczniejsze są kobiety, osoby w średnim wieku, częściej mieszkające w miastach, charakteryzujące się wyższymi poziomami wykształcenia, wyższymi miejscami w strukturze społeczno-zawodowej i rzadszym uczestnictwem w praktykach religijnych (Pankowski, 2017). Z kolei, w elektoracie PiS liczniejsi stali się mieszkańcy wsi, osoby starsze, legitymujące się niższymi poziomami wykształcenia.

Niemałe różnice w składach społecznych i zawodowych elektoratów obu partii czasem znajdują swój wyraz w opisach, w których wielkomiejscy, lepiej wykształceni, zamożniejsi i bardziej liberalni wyborcy PO, przeciwstawiani są wiejskim, gorzej wykształconym, biedniejszym i bardziej konserwatywnym wyborcom PiS. Ta obrazowa figura retoryczna, wykorzystywana w publicystyce - a jeszcze częściej w anonimowych, poważnych (przez zwolenników PO) lub prześmiewczych (przez zwolenników PiS) internetowych komentarzach - do wyjaśniania odmienności obu elektoratów, w niewielkim stopniu przybliża do odpowiedzi na pytanie: w czym tkwi istota radykalnego podziału politycznego w Polsce na zwolenników PO i PiS?

Tylko częściowo przybliżają do odpowiedzi na to pytanie różnice w poglądach zwolenników obu partii na ustrój gospodarczy, społeczny i polityczny kraju. Tylko częściowo, gdyż - jak dowodzą wyniki badań z 2005 i 2016 roku - przekonania zwolenników PO i PiS w wielu kwestiach były do siebie zbliżone (Roguska, 2005; Roguska, 2016). W 2005 roku należały do nich m.in. poglądy na temat: dekomunizacji, prywatyzacji przedsiębiorstw państwowych i jej tempa, polityki społecznej państwa, polityki za- 
trudnienia, systemu podatkowego, sposobów walki z przestępczością, stosunków między państwem a Kościołem, rozwiązań prawnych dotyczących przerywania ciąży. We wszystkich wymienionych obszarach problemowych można było mówić co najwyżej o nieco innym rozłożeniu akcentów w przekonaniach zwolenników PO w porównaniu z opiniami zwolenników PiS. Badania zrealizowane 11 lat później ukazały zbieżność poglądów sympatyków obu partii w takich obszarach jak: polityka społeczna, polityka zatrudnienia, system podatkowy, polityka wschodnia państwa (Roguska, 2016).

Rezultaty tych badań ujawniły także obszary rozbieżności poglądów omawianych elektoratów. Dotyczą one między innymi stosunku do integracji europejskiej. O ile połowa potencjalnego elektoratu PiS (49,0\%) pozostała zwolennikami zachowania daleko idącej niezależności Polski w UE, to wśród zwolenników PO pogląd ten stał się wyraźnie mniejszościowy (17,0\%). Dominujący stali się w tym elektoracie zwolennicy ściślejszej integracji Polski ze strukturami UE (66,0\%). Odsetek takich osób wśród sympatyków PiS wzrósł tylko o $1 \%$ (do $27,0 \%$ ). Równie symptomatyczne są rozbieżności poglądów obu potencjalnych elektoratów na temat zakresu wpływu religii na rozwiązania prawne i decyzje polityczne. O ile sympatycy PiS częściej niż 11 lat wcześniej są zwolennikami całkowitego zakazu przerywania ciąży $(64,0 \%)$, to wśród zwolenników PO opinie takie stały się zdecydowanie rzadsze (27,0\%) (Roguska, 2016).

Zmiany w poglądach zwolenników obu partii w wymienionych obszarach są skorelowane z kierunkiem ewolucji ich politycznych autodeklaracji. W 2005 roku taki sam odsetek potencjalnych wyborców każdej z partii określał swe poglądy jako prawicowe $(60,0 \%)$. Odsetki identyfikujących się z lewicą nie przekraczały wówczas w żadnym z elektoratów 10,0\%. Późniejsze zmiany, zarówno w strukturach elektoratów, jak i poglądach ich członków doprowadziły do znaczących przeobrażeń w sferze deklarowanych identyfikacji politycznych. W potencjalnym elektoracie PiS dominującą orientacją pozostaje prawica $(68,0 \%)$. Identyfikacje centrowe $(16,0 \%)$ i lewicowe $(4,0 \%)$ deklarowane są zdecydowanie rzadziej. Z kolei, w potencjalnym elektoracie PO trudno mówić o jakiejś dominującej orientacji - stosunkowo najliczniejszy odsetek osób identyfikuje się z centrum $(35,0 \%)$, nieco mniejszy z lewicą $(28,0 \%)$, a jeszcze mniejszy z prawicą (24,0\%) (Pankowski, 2017, s. 11).

\section{Elektoraty PO i PiS - od niechęci do dwuplemienności}

Chociaż niektóre z poglądów, podobnie jak część różnic demograficznych, społecznych i zawodowych między elektoratami PO i PiS są dość istotnie od siebie odmienne, to trudno znaleźć w nich przekonujące uzasadnienie dla skali i natężenia konfliktu między partiami oraz ich zwolennikami. Jego intensywność i wszechobecność, gdyż spory toczone są w wielu środowiskach, skłania publicystów i obserwatorów życia publicznego do formułowania tezy o dwóch metaforycznych Polskach, o dwóch obcych sobie plemionach (Migalski, 2016; Warzecha, 2016). W jaki sposób wytłumaczyć tę „dwuplemienność" i jej trwałość?

Symbolicznym początkiem jej budowania były nieudane rokowania, podjęte przez dwie zwycięskie partie po wyborach parlamentarnych w 2005 roku, w sprawie utworzenia koalicyjnego rządu. Pomimo tego, że powstanie wspólnego rządu 
politycy obu partii zapowiadali zarówno przed kampanią wyborczą, jak i w jej trakcie, a w okresie negocjacji koalicyjnych o powstaniu rządu POPiS przekonana była zdecydowana większość zwolenników obu partii (79,0\% sympatyków PiS i 75,0\% sympatyków PO), do zawarcia koalicji nie doszło (Roguska, 2005a, s. 1). Wyniki realizowanych wówczas badań świadczą o tym, że był to bardzo trudny moment dla obu elektoratów. Zdecydowana większość elektoratu PO (70,0\%) i znacząca część elektoratu PiS (39,0\%) czuła się zawiedziona, że nie doszło do utworzenia rządu PO i PiS. Odpowiedzialnością za niepowodzenie rozmów koalicyjnych zwolennicy obu partii obarczali najczęściej drugą stronę (około połowy zwolenników obu partii), ale liczne odsetki wyborców jednej i drugiej partii (39,0\% PO i 35,0\% PiS) winą za brak porozumienia obciążali obie partie (Roguska, 2005b). Zapoczątkowany w tym okresie fundamentalny spór między PO a PiS stał się rodzajem nowej „wojny na górze” w obozie solidarnościowym, skutkującej podziałem społecznym, który w kolejnych latach nabrał równie doniosłego charakteru, jak wcześniej podział postkomunistyczny (Grabowska, 2004).

Uzasadnieniem odwołania się do takich kategorii pojęciowych, jak podział postkomunistyczny, czy „wojna na górze”, jest nie tylko fakt, że nieudane rozmowy koalicyjne były aktem fundacyjnym podziału równie doniosłego, jak poprzednie, ale także to, że - podobnie jak w tamtych podziałach - w tym, zapoczątkowanym w 2005 roku bardzo istotną rolę odegrały narracje, pojmowane jako sposoby rozumienia świata, czyli schematy strukturyzowania danych i operowania nimi (Wasilewski, Olczyk, 2017, s. 37). Zasadne wydaje się twierdzenie, że istotną rolę w krystalizacji podziału na zwolenników PO i PiS odegrały nie tyle nieudane rokowania koalicyjne i wydarzenia będące ich konsekwencją (czyli utworzenie rządu mniejszościowego, a później koalicyjnego przez PiS oraz przejście do opozycji PO), co zapoczątkowane wówczas, nasycone silnym ładunkiem emocjonalnym, partyjne narracje wyjaśniające wydarzenia oraz zawierające przekaz na temat partii - niedoszłego koalicjanta, jej liderze/liderach, członkach i sympatykach oraz przypisywanych tym wszystkim osobom cechach i motywacjach. Wyobrażenia te, najczęściej konfrontowane z dotyczącymi partii uznawanej za swoją, składają się na szersze wielowątkowe narracje, z uwypuklonymi w nich takimi elementami, które są istotne dla tożsamości politycznej sympatyków danego ugrupowania.

Do czasu wyborów parlamentarnych w 2005 roku, narracje PO i PiS - pomimo tego, że kampania wyborcza ujawniła, że istnieją między nimi pewne różnice - były względnie spójne. Ich wspólnym fundamentem było przekonanie o konieczności dokonania w Polsce radykalnych zmian w sferze polityki i moralności, chęć oczyszczenia polityki z korupcyjnych powiązań oraz odsunięcia od władzy partii postkomunistycznej (SLD), która w obu narracjach była kluczowym kreatorem dotychczasowego porządku politycznego. Założenia te wpisywały się w hasło budowy „IV Rzeczpospolitej”, którym w kampanii wyborczej posługiwały się obie partie. Po zakończonych fiaskiem rozmowach koalicyjnych, w równolegle tworzonych i rozwijanych, przez gremia przywódcze obu partii, narracjach, miejsce dotychczasowego przeciwnika, jakim dla obu partii był dotychczas SLD, zajął dotychczasowy sojusznik polityczny, niedoszły koalicjant, obsadzony w nowej roli - wroga. Dostrzegane już w okresie poprzedzającym kampanię wyborczą, jak i w jej trakcie, różnice w kierowanych do wyborców przekazach politycz- 
nych obu partii, zaczęły odgrywać kluczową rolę w budowie nowych narracji partyjnych, uwzględniających nowe okoliczności, czyli rozpad koalicji. Ważnym elementem wspólnym nowych narracji obu partii było hasło zdrady ideałów IV Rzeczpospolitej przez dotychczasowego sojusznika politycznego. Pogląd ten w narracji jednej partii (PO) łączony był z podejrzeniami drugiej (PiS) o skłonności autorytarne, o dążenie do budowy państwa policyjnego i ograniczenie swobód obywatelskich, a w narracji drugiej (PiS), z formułowanymi pod adresem oponentów (PO), zarzutami o pozorowaną, a nie rzeczywistą chęć naprawy państwa i sprzyjanie „układowi” rządzącemu Polską, a nawet przynależność do niego.

Relacje między PO i PiS szybko zaczęły nabierać cech kooperacji negatywnej (Karwat, 2017, s. 136) lub - dosadniej rzecz ujmując - konfliktu antagonistycznego, to znaczy takiego, że: „nie mieści się w wyobraźni stron konfrontacji, rozwiązanie sprzeczności interesów i przeciwieństwa dążeń przez porozumienie, kompromis lub przetarg, w ramach istniejących stosunków i wspólnie uznawanych reguł; jedyne zaś rozwiązanie, jakie się nasuwa, polega na przekreśleniu jakiejkolwiek wspólnoty i na usunięciu ze wspólnej przestrzeni albo na zniszczeniu lub w każdym razie na pognębieniu i podporządkowaniu drugiej strony. Pretendenci do tych samych dóbr nie są tu rywalami, konkurentami ani nawet przeciwnikami, którzy, rozgrywając ostrą walkę, respektują nawzajem swoją tożsamość, godność i prawo do istnienia, lecz wrogami, dążącymi do eliminacji żywej przeszkody" (Karwat. 2017, s. 137-138).

Ten typ stosunków między partiami pozwala je nazwać antagonizmem manichejskim. Do głównych konsekwencji tego typu relacji, jak trafnie zauważa Jacek Ziółkowski, można zaliczyć: ,powstanie dwóch homogenicznych, wrogich obozów; wyostrzenie (i kumulację w osobie wrogów) różnic, np. ekonomicznych, kulturowych, ideologicznych, światopoglądowych, etycznych; postrzeganie wrogów na zasadzie kontrastu; izolację stron, hermetyzację poszczególnych obozów; brak woli komunikowania, porozumienia, dialogu. W wyniku antagonizacji powstają dwa wrogie podmioty lub obozy. Członkowie systemu poddanego presji narracji antagonistycznej definiują świat przez pryzmat sfery „my” (uciśnieni, bohaterscy, honorowi, godni itp.) oraz sfery „,nie my”. Tu „inni”, czyli „obcy”, traktowani są jako wrogowie en bloc. Przyjmuje się często, iż otoczenie danej wspólnoty tworzy zwarty zbiór, układ wrogów" (Ziółkowski, 2017, s. 101). Antagonizm między PO i PiS w niemal modelowy sposób wypełnia treścią wymienione cechy antagonizmu manichejskiego.

$\mathrm{Na}$ totalny charakter międzypartyjnej negacji zwraca uwagę Marek Górka, który relacje między PO i PiS po 2005 roku, nazywa historią wzajemnych ataków, której kreowaniu wydatnie sprzyjały częste kampanie wyborcze: „Paradoxically, the political opponent becomes the reference point for the identity of the party. So constructed relation based on the oppositeness helps to clarify your own programme, to mobilize voters and makes the action more detailed. This is the program and the image subordinate to the total negation. It was difficult to find one area of life to which both formations are compatible. Thereby, the discreditation turns to a total character. It is an expression - at policy level - of brutalization of public life. When analyzing the confrontation of both post - solidarity camps there can be drawn a conclusion that a form of rivalry started to cross the boundaries of once set rules not only in the period of the campaign but also in the period of governance" (Górka, 2013, s. 201). 
Ten sam autor podkreśla również wagę wpływu mediów na kampanie polityczne: „The characteristic feature of political campaigns is its confrontational nature, which from the point of view of the media is in their interest. The media have become an active player in the political competition. Thus, the factor that often decides on the uniqueness of choices is merely an ideology or political programme, but image created in media whose main goal is to pay voters' attention to emotional content. Selectivity of relationships and events is therefore an effective tool to determine and suggest to customers a significant breakthrough moments before the election campaign" (Górka, 2013, s. 187).

Aktywna rola istotnej części mediów w Polsce wyraża się nie tylko w relacjonowaniu politycznej rywalizacji między PO i PiS, ale także w jej podtrzymywaniu i eskalacji. Wyznaczając hierarchię tematów, wyjaskrawiając, ramując (Castells, 2013, s. 164-167), media, używając wydarzeń, zjawisk, problemów, czy osób, aktywnie uczestniczą w budowie dwóch narracji o współczesnej Polsce, jej przeszłości i przyszłości. Lech Wałęsa, obrady Okrągłego Stołu, rząd Jana Olszewskiego, katastrofa smoleńska to tylko niektóre przykłady tematów ogniskujących opinie, sądy, komentarze, z których budowane są narracje sprzyjające krystalizacji tożsamości politycznej każdej ze stron sporu. W podsumowaniu wyników badań, których celem była analiza zawartości czterech polskich dzienników ogólnoinformacyjnych: „Gazety Polskiej Codziennie”, „Gazety Wyborczej”, „Naszego Dziennika” i „Rzeczpospolitej”, autorka, charakteryzując trzy pierwsze tytuły stwierdziła: ,analiza materiałów dziennikarskich i uzyskane wyniki badań potwierdzają tezę o stronniczości, wyrazistości ideologicznej i zaangażowaniu politycznym dzienników" (Olechowska, 2017, s. 126). Podobne tendencje są charakterystyczne także dla tygodników opinii (Kotras, 2013; Brzoza, Głuszek-Szafraniec, Szostok, 2017) oraz dla głównych programów informacyjnych dwóch największych stacji telewizyjnych, których wyniki analiz autorka obrazowo puentuje: „oglądając oba serwisy, można mieć wrażenie, że żyje się w alternatywnych rzeczywistościach, w których dobro i zło, biel i czerń istnieją po przeciwnych stronach" (Seklecka, 2017, s. 150).

Wyniki badań poświęcone użytkownikom mediów potwierdzają przypuszczenia, że wyborcy PO i Nowoczesnej oraz PiS uczestniczą w radykalnie odmiennych przestrzeniach informacyjnych. Mają swoje ulubione media, z których czerpią informacje o wydarzeniach w kraju i na świecie, uznają je za wiarygodne, obdarzają zaufaniem, odmawiając jednocześnie wiarygodności i zaufania nadawcom identyfikowanym, jako podmioty wspierające konkurencję polityczną (Wenzel, 2018; Omyła-Rudzka, Feliksiak, 2019).

\section{Zakończenie}

W charakterystykach zwolenników partii politycznych podkreśla się często wyraźne współwystępowanie w ich poglądach elementów sympatii i zaufania do partii popieranej oraz niechęci, a nawet odrzucenia w stosunku do innych partii. W Polsce zjawisko to jest charakterystyczne dla elektoratów wszystkich największych partii politycznych (Kowalczuk, 2015; Cybulska, 2016). Wyborcy PO, PiS, partii Nowoczesna, Kukiz'15, 
PSL i SLD w swych opiniach o partiach i ruchach politycznych, z różnym natężeniem i w różnych proporcjach, łączą sympatię jaką obdarzają partię, na którą chcieliby oddać swój głos z niechęcią do innych partii. Najbardziej spektakularną formę omawiane zjawisko przybiera jednak w przypadku elektoratów PO i PiS.

Utrzymująca się od 2005 roku polaryzacja wyborców na sympatyków PO i PiS (chociaż być może trafniej istotę politycznego pęknięcia populacji osób biorących udział w wyborach we współczesnej Polsce oddaje podział na przeciwników PO i przeciwników PiS) ma podobnie fundamentalny charakter, jak polityczny podział Polaków na zwolenników strony solidarnościowej i postkomunistycznej na przełomie lat 80. i 90. XX w. Tamten podział, znajdujący odzwierciedlenie w głosowaniu na SLD, bądź na partie postsolidarnościowe, swą znaczącą żywotność zachował do wyborów parlamentarnych przeprowadzonych jesienią 2005 roku, po których stracił na znaczeniu, na rzecz tego, który jest przedmiotem zainteresowania w tekście.

Obydwie strony tego, daleko wykraczającego poza politykę, sporu tworzą dwie nierozumiejące się zbiorowości. Jednym z symptomatycznych wskaźników dystansu jaki je dzieli jest treść licznych internetowych komentarzy towarzyszących publikacji wyników sondaży poparcia dla obu partii. Wynika z nich, że zwolennicy każdej ze stron politycznego sporu - jak sami przyznają - nie rozumieją zarówno decyzji swych przeciwników, jak i towarzyszących im motywacji. Źródeł żywotności podziału upatrywać przede wszystkim można w różnicach światopoglądowych i budowanych na nich, silnie nasyconych emocjonalnie, narracjach, z których jedna jest zdecydowanie bliższa orientacji liberalno-lewicowej, a druga konserwatywno-prawicowej. A o konsensus między nimi raczej trudno.

\section{Bibliografia}

Berelson B. R., Lazarsfeld P. F., McPhee W. N. (1954), Voting: A Study of Opinion Formation in a Presidential Campaign, University of Chicago Press, Chicago.

Brzoza K., Głuszek-Szafraniec D., Szostok P. (2017), Upolitycznienie przekazu prasowego w wybranych polskich tygodnikach opinii. Wstęny raport z badań, „Political Preferences”, nr 16, s. $81-106$.

Castells M. (2013), Władza komunikacji, Wydawnictwo Naukowe PWN, Warszawa.

Cybulska A. (2005), Układ poparcia dla partii politycznych przed wyborami do parlamentu, Komunikat z badań BS/100/2005, CBOS, Warszawa.

Cybulska A. (2007), Siła preferencji politycznych, alternatywy wyborcze i elektoraty negatywne, Komunikat z badań BS/149/2007, CBOS, Warszawa.

Cybulska A. (2010), Alternatywy wyborcze i elektoraty negatywne, Komunikat z badań BS/151/2010, CBOS, Warszawa.

Cybulska A. (2015), Sympatie i antypatie wyborcze, Komunikat z badań nr 111/2015, CBOS, Warszawa.

Cybulska A. (2016), Społeczna aprobata i dezaprobata partii i ruchów politycznych, Komunikat z badań 94/2016, CBOS, Warszawa.

Cybulska A. (2017), Identyfikacje partyjne, alternatywy wyborcze i elektoraty negatywne na pótmetku kadencji Sejmu, Komunikat z badań nr 135/2017, CBOS, Warszawa.

Cybulska A. (2019), Struktura sceny politycznej: sympatie i antypatie w elektoratach głównych partii, Komunikat z badań nr 39/2019, CBOS, Warszawa. 
Cześnik M. (2007), Partycypacja wyborcza w Polsce. Perspektywa porównawcza, Wydawnictwo Naukowe Scholar, Warszawa.

Górka M. (2013), Determinants of Political Decisions in the Polish Political System, „Polish Political Science", nr XLII, s. 185-206.

Grabowska M. (2004), Podziat postkomunistyczny. Społeczne podstawy polityki w Polsce po 1989 roku, Wydawnictwo Naukowe Scholar, Warszawa.

Jasiewicz K. (2002), Portfel czy różaniec? Wzory zachowań wyborczych Polaków w latach 1995-2001, w: System partyjny i zachowania wyborcze: dekada polskich doświadczeń, red. R. Markowski, ISP PAN, Fundacja im. Friedricha Eberta, Warszawa.

Karwat M. (2017), Spirala przemocy w konfliktach społecznych, „Wrocławskie Studia Politologiczne”, nr 22, s. 135-153.

Kotras M. (2013), Dwa światy, dwie narracje. Retoryka tygodników opinii „W Sieci” i „Polityka”, „Acta Universitatis Lodziensis. Folia Sociologica”, nr 46, s. 89-109.

Kowalczuk K. (2015), Sympatia i niechęć do partii i inicjatyw politycznych, Komunikat z badań 99/2015, CBOS, Warszawa.

Migalski M. (2016), Starcie dwóch światów, czyli wspólnotowcy kontra indywidualiści, „Rzeczpospolita", nr 3 (10336), z dnia 5-6.01.2016 r.

Olechowska P. (2017), Stopień stronniczości polskich dzienników ogólnoinformacyjnych (wybrane wyznaczniki), „Political Preferences”, nr 16, s. 107-130.

Omyła-Rudzka M., Feliksiak M. (2019), Wiarygodność mediów, Komunikat z badań nr 70/2019, CBOS, Warszawa.

Pankowski K. (2001), Przed wyborami parlamentarnymi - pewność glosowania, alternatywy wyborcze, elektoraty negatywne, Komunikat z badań BS/85/2001, CBOS, Warszawa.

Pankowski K. (2001a), Wybory parlamentarne - pewność głosowania, alternatywy wyborcze, elektoraty negatywne, uzasadnienia decyzji wyborczych, Komunikat z badań BS/100/2001, CBOS, Warszawa.

Pankowski K. (2017), Elektoraty PO i PiS w ostatnich dwunastu latach, Komunikat z badań nr 130/2017, CBOS, Warszawa.

Raciborski J. (2003), Wybory i wyborcy, w: Demokracja polska 1989-2003, red. J. J. Wiatr, J. Raciborski, J. Bartkowski, B. Frątczak-Rudnicka, J. Kilias, Wydawnictwo Naukowe Scholar, Warszawa.

Roguska B. (2005), Potencjalne elektoraty o istotnych kwestiach społeczno-politycznych, Komunikat z badań BS/130/2005, CBOS, Warszawa.

Roguska B. (2005a), Opinie o koalicji PiS i PO, Komunikat z badań BS/166/2005, CBOS, Warszawa.

Roguska B. (2005b), O niedoszłej $i$ ewentualnych koalicjach rzadowych, Komunikat z badań BS/190/2005, CBOS, Warszawa.

Roguska B. (2016), Elektoraty partyjne - charakterystyka pogladów, Komunikat z badań nr 95/2016, CBOS, Warszawa.

Seklecka A. (2017), „Alternatywne światy”, czyli różnice $w$ relacjonowaniu wydarzeń $w$ „Faktach” TVN $i$,,Wiadomościach” TVP, „Political Preferences”, nr 16, s. 131-152.

Warzecha Ł. (2016), Lemingi Kaczyńskiego, „Rzeczpospolita”, nr 67 (10400), z dnia 21.03.2016 r.

Wasilewski J., Olczyk T. (2017), Storytelling jako narzędzie marketingu politycznego - model, „Studia Politologiczne", nr 45, s. 36-53.

Wenzel M. (2018), News Consumption and Political Party Preferences in Poland, „Political Preferences", $\mathrm{nr} 18$, s. 57-74.

Ziółkowski J. (2017), Wróg w politycznych narracjach antagonizmu manichejskiego, „Wrocławskie Studia Politologiczne", nr 22, s. 92-107. 


\title{
Political parties and their electorates. From sympathy to antagonism. Based on the Civic Platform (PO) and Law and Justice (PiS)
}

\begin{abstract}
Summary
Since 2005, political life in Poland has been largely dominated by a dispute between two parties: Civic Platform (PO) and Law and Justice (PiS). This dispute is not just a rivalry between party leaders on political programs. It is rather a confrontation of the antagonistic views of the voters and supporters of both parties. The unsuccessful talks between the leadership groups of both parties, which did not lead to the formation of a coalition government in 2005 are often referred as a symbolic beginning of this conflict. The intensity of this dispute, prompts the observers of public and political life to formulate a thesis about two metaphoric Polands, two tribes that are alien to each other. Authors of the scientific and journalistic analyses of this phenomenon often point out the differences in demographic and social characteristics of the electorates of both parties. However, these differences are less important than dissimilarities in views and opinions of PO and PiS supporters on events, phenomena and persons relevant to party identities. The media also play a crucial role in supporting and reproducing different views of supporters of both parties. The purpose of this paper is to present a characteristics of the supporters of both parties and to analyze the evolution of their political likes and dislikes in the last several years. The conclusions are based on a analysis of the data collected in the years 2001-2019 by the Public Opinion Research Center (CBOS) and by other researchers.
\end{abstract}

Key words: Civic Platform, Law and Justice, political likes and dislikes, electorate, narration, antagonistic conflict 
